\title{
Perawatan Lansia: Menerjemahkan Peraturan Nasional ke dalam Program Lokal di Kota Yogyakarta
}

\author{
Yuni Hastuti ${ }^{1}$, Muhadjir Darwin², Sukamdi ${ }^{3}$, dan Agus Heruanto Hadna² \\ ${ }^{1}$ Magister dan Doktor Studi Kebijakan, Fakultas Pascasarjana, Universitas Gadjah Mada, \\ Yogyakarta, ${ }^{2}$ Fakultas IImu Sosial dan IImu Politik, Universitas Gadjah Mada, Yogyakarta, \\ ${ }^{3}$ Fakultas Geografi, Universitas Gadjah Mada, Yogyakarta
}

Korespondensi:Yuni Hastuti (e-mail: yunihastuti81@gmail.com)

\begin{abstract}
Abstrak
Salah satu isu penting terkait dengan perawatan lansia adalah pertambahan jumlah penduduk usia lanjut yang sangat signifikan. Bersamaan dengan hal tersebut, permasalahan yang dihadapi lansia juga meningkat dan bervariasi. Penelitian ini bertujuan untuk mengkaji memadai tidaknya isi regulasi yang menjadi dasar perumusan kebijakan dan program perawatan lansia. Di samping itu, penelitian ini juga untuk mengidentifikasi turunan regulasi yang ada dan akan menjadi program perawatan lansia di Kota Yogyakarta. Untuk menjawab permasalahan tersebut, penelitian dilakukan dengan mengombinasikan tiga cara, yaitu studi dokumen, survei, dan studi kualitatif melalui wawancara mendalam kepada pemangku kepentingan di Kota Yogyakarta. Hasil penelitian menunjukkan bahwa secara normatif, regulasi di tingkat nasional maupun provinsi cukup memadai sebagai landasan perumusan kebijakan perawatan lansia. Namun, permasalahan yang cukup serius adalah operasionalisasi peraturan ke dalam program. Mandat yang ada di dalam undang-undang atau peraturan lainnya belum dapat sepenuhnya dipenuhi pada level program maupun kegiatan. Pada tingkat operasional beberapa program yang telah dilakukan di Kota Yogyakarta telah mampu merespons kebutuhan lansia. Survei menunjukkan bahwa sebagian besar lansia membutuhkan perkumpulan sesama lansia dan hal ini telah direspons dengan program Rusela (Rumah Sehat Lansia). Akan tetapi, masih terdapat beberapa kebutuhan, terutama menyangkut ekonomi dan kesehatan, yang belum direspons secara optimal.
\end{abstract}

Kata kunci: kebijakan perawatan lansia; implementasi; program kelanjutusiaan 


\title{
Elderly Care: Translating National Regulations into Local Programs in City of Yogyakarta
}

\begin{abstract}
One of the important issues related to the elderly is the elder people is significantly increase in the number. In accordance to that, the problems faced by the elderly are also increase and vary. This study aims to examine whether the regulation as the basis for policy formulation and elderly care programs is sufficient. Besides that, this study also tends to identify the translating of existing regulations into elderly care programs in City of Yogyakarta. To answer these problems, research was conducted by combining three ways: document study, survey and qualitative study through in-depth interviews with stakeholders in City of Yogyakarta.The results show that normatively regulation at the national and provincial levels are sufficient as a basis for the formulation of elderly care policies. Nevertheless another serious problem is the operationalization of regulations into the program. The mandate in the law or other regulations was not fully be fulfilled at the level of programs and activities. At the operational level, several programs that have been carried out in City of Yogyakarta have been able to respond to the needs of the elderly. The survey shows that most of the elderly need to join a gathering of fellow seniors and this has been responded to by Rusela program (healthy elderly homes). However there are still some needs, especially regarding the economy and health that have not been responded optimally.
\end{abstract}

Keywords: elderly care policy; implementation; elderly program

\section{Pendahuluan}

Permasalahan perawatan lansia di Indonesia menjadi sangat penting untuk diperhatikan karena beberapa alasan. Pertama, jumlah penduduk usia lanjut mengalami peningkatan yang signifikan selama empat puluh tahun terakhir. Hal itu ditunjukkan dengan adanya peningkatan jumlah lansia dari 5 juta tahun 1970 menjadi 18 juta tahun 2010. Jumlah tersebut diproyeksikan akan bertambah hingga lebih dari 71 juta tahun 2050 (Lembaga Demografi UI dan HelpAge International, 2012). Dari sisi persentase, jumlah lansia juga mengalami peningkatan yang signifikan, yaitu dari 4,5 persen tahun 1971 dan diperkirakan meningkat menjadi 19,89 persen tahun 2045 (BPPN, BPS dan UNFPA, 2018). Hal itu menunjukkan bahwa Indonesia akan segera memasuki era population aging.
Salah satu daerah di Indonesia yang memiliki perkembangan lansia cukup pesat adalah Daerah Istimewa Yogyakarta (DIY). Hasil proyeksi penduduk menunjukkan bahwa penduduk lansia (60 tahun ke atas) di DIY tahun 2045 mengalami peningkatan menjadi 19,7 persen dari 13,9 persen tahun 2015. Angka ini jauh lebih tinggi dibandingkan dengan angka nasional dan provinsi yang lain di Indonesia. Secara absolut, jumlah lansia diperkirakan akan mengalami peningkatan dari 511.700 jiwa tahun 2015 menjadi 1.024.800 jiwa tahun 2045 (BPPN, BPS, dan UNFPA, 2018). Perubahan angka tersebut menunjukkan bahwa struktur penduduk DIY telah terlebih dulu masuk ke struktur tua (ageing population) dibandingkan dengan angka nasional. Sementara itu, perbandingan antara angka ketergantungan lansia antara Indonesia adalah 14,02 persen dan di DIY mencapai angka 21,53 (BPS, 2018b). Hal 
itu berarti bahwa Yogyakarta mengalami permasalahan yang lebih besar dibandingkan dengan nasional.

Pola yang mirip ditemukan di Kota Yogyakarta, yang ditunjukkan dengan adanya peningkatan jumlah lansia yang cukup signifikan. Pada 2016 jumlah populasi lansia di Kota Yogyakarta adalah 43.721 jiwa. Badan PusatStatistikDIY (2018a)memprediksiangka tersebut akan terus mengalami peningkatan setiap tahunnya dan pada 2025 diperkirakan akan meningkat menjadi 56.949 jiwa. Masalah yang muncul kemudian adalah meningkatnya angka rasio ketergantungan lansia sebagai indikator bertambahnya beban yang harus ditanggung penduduk usia produktif. Pada skala yang lebih luas, hal tersebut juga berarti meningkatnya beban keluarga, masyarakat, dan pemerintah, terutama terkait dengan kebutuhan ekonomi, kesehatan, serta sosial psikologis lansia (Rustatiningsih, 2015).

Pembicaraan mengenai lansia tidak hanya penting karena jumlahnya yang terus meningkat, tetapi juga terkait dengan permasalahan yang dihadapi oleh lansia. Terdapat lima permasalahan yang dihadapi oleh lansia (Kementerian Koordinator Bidang Pembangunan Manusia dan Kebudayaan, 2015), yaitu masalah ekonomi, psikologis, sosial, fisik, dan psikis. BPS (2018b) menyebutkan bahwa pada 2017 terdapat 48,91 persen lansia di Indonesia yang mengalami keluhan kesakitan. Hal ini menjadi permasalahan yang lebih serius karena banyak lansia yang belum tersentuh programprogram pemerintah (Astuti, dkk., 2016).

Permasalahan sosial ditandai dengan berkurangnya intensitas interaksi sosial yang dilakukan lansia, baik dalam lingkungan keluarga maupun masyarakat, serta kehilangan teman sebaya (peer group). Hal ini menyebabkan munculnya perasaan kesepian dan kehilangan kontak dengan sesama lansia.
Data Susenas (2017) menunjukkan bahwa hampir 60 persen lansia Indonesia memiliki pasangan, sedangkan sisanya tidak memiliki pasangan, baik karena belum kawin, cerai hidup maupun cerai mati. Berdasarkan status tinggalnya, masih terdapat 9,8 persen lansia Indonesia yang tinggal sendiri dan 18,89 persen lansia yang hanya tinggal bersama pasangannya (BPS, 2018b).

Sementara itu, hasil penelitian Suriastini, dkk. (2016) menunjukkan bahwa persentase lansia di Yogyakarta yang mengalami demensia sebesar 20,1 persen. Hasil penelitian tersebut juga menunjukkan bahwa prevalensi demensia meningkat sejalan dengan meningkatnya umur. Pada umur 6064 prevalensi demensia tercatat 7,0 persen dan pada umur $90+$ meningkat sepuluh kali lipat menjadi 70,4 persen. Hasil lain yang menarik memperlihatkan bahwa prevalensi untuk perempuan lebih tinggi dibandingkan dengan laki-laki, serta lansia yang tinggal di desa memiliki prevalensi yang lebih tinggi dibandingkan dengan yang tinggal di kota.

Pembahasan selanjutnya adalah tentang ekonomi. Permasalahan ekonomi berakar pada fakta bahwa lansia kehilangan sumber pendapatan karena permasalahan fisik dan kesehatan serta sosial, yang tidak memungkinkan mereka produktif. Permasalahan ini, terutama untuk lansia perempuan yang pada awalnya tergantung pada di sektor pertanian. Permasalahan ini semakin parah dengan hilangnya dukungan ekonomi dan sosial dari penduduk di sekitarnya akibat berkembangnya sifat individualis. Kehidupan ekonomi lansia di Indonesia tergolong memprihatinkan. Hal itu berdasarkan data yang menunjukkan lansia di Indonesia masih didominasi oleh lansia dengan status rumah tangga dengan kelompok pengeluaran 40 persen terbawah yang jumlahnya mencapai 43,18 persen (BPS, 2018b). 
Dalam rangka merespons permasalahan tersebut di atas, pemerintah telah melakukan berbagai usaha, baik secara normatif melalui undang-undang, peraturan pelaksanaan di bawahnya, maupun program yang secara operasional memberikan dukungan dan perawatan lansia. Sebagai contoh, hal ini dapat dilihat dari Undang-Undang Nomor 13 Tahun 1998 tentang Kesejahteraan Lanjut Usia. Secara khusus, hal itu tercatat pada beberapa ayat di pasal 5 sebagai berikut. Ayat (1) menyatakan bahwa lanjut usia mempunyai hak yang sama dalam kehidupan bermasyarakat, berbangsa, dan bernegara. Kemudian ayat (2) menyatakan bahwa sebagai penghormatan dan penghargaan kepada lanjut usia, mereka diberikan hak untuk meningkatkan kesejahteraan sosial yang meliputi a) pelayanan keagamaan dan mental spiritual; b) pelayanan kesehatan; c) pelayanan kesempatan kerja; d) pelayanan pendidikan dan pelatihan; e) kemudahan dalam penggunaan fasilitas, sarana, dan prasarana umum; f) kemudahan dalam layanan bantuan hukum; g) perlindungan sosial; dan h) bantuan sosial. Ayat (3) menjelaskan bahwa bagi lansia tidak potensial, mendapatkan kemudahan sebagaimana dimaksud ayat (2) kecuali huruf "c", huruf "d", dan huruf "h". Selanjutnya ayat (4) bagi lanjut usia potensial, mereka mendapatkan kemudahan sebagaimana dimaksud ayat (2) kecuali huruf "g" (Astuti, dkk., 2016).

Regulasi tentang kesejahteraan lansia di level pusat merupakan acuan bagi pemerintah daerah untuk merumuskan regulasi atau program kelanjutusiaan. Thoha (2012) memberikan penafsiran tentang kebijakan publik yang merupakan hasil rumusan dari suatu pemerintahan. Dengan demikian, amanat undang-undang pada level kota dilaksanakan dengan perumusan program-program utama yang berkaitan dengan kesejahteraan lansia (Rangkoly, dkk., 2014). Program yang dibuat oleh pemerintah daerah untuk mengakomodasi amanat undang-undang tidak serta-merta memasukkan penerapan seluruh aspek kesejahteraan lansia. Dalam hal ini, pemerintah daerah melalui kewenangan umumnya mengambil prioritas program, seperti Pemerintah Kota Yogyakarta yang condong pada program kesehatan bagi lansia.

Dunn (1994) menyatakan bahwa dalam proses kebijakan publik, suatu program kebijakan harus diimplementasikan agar dampak atau tujuan yang dinginkan dapat direalisasikan. Hal ini sesuai dengan pernyataan Ramdhani dan Ramdhani (2017) yang menyatakan pelaksanaan kebijakan secara sederhana adalah pelaksanaan atau penerapan suatu kebijakan. Implementasi kebijakan dimaksudkan supaya regulasi dan kebijakan yang telah dibuat dapat terealisasi dan memberikan manfaat secara nyata untuk mesyarakat, khususnya lansia.

Dalam kaitannya dengan penjelasan di atas, muncul permasalahan penting yang menarik untuk dikaji. Pertama, apakah regulasi yang ada sampai saat ini, baik di tingkat nasional, provinsi, maupun kabupaten/kota telah mencukupi sebagai landasan bagi program pelayanan lansia? Kedua, apakah regulasi di tingkat provinsi konsisten dengan tingkat nasional dan regulasi di tingkat kabupaten/kota juga konsisten dengan regulasi di tingkat provinsi? Ketiga, bagaimana regulasi yang telah ada diterjemahkan ke dalam program dan kegiatan di tingkat kabupaten/ kota? Penelitian ini bertujuan untuk menjawab pertanyaan tersebut.

\section{Metode Penelitian}

Penelitian ini merupakan bagian dari kajian yang lebih luas untuk mengintegrasikan IT (informasi dan teknologi) dalam pengembangan sistem perawatan lansia di 
Kota Yogyakarta. Penelitian ini merupakan hasil tahap pertama kajian tersebut. Penelitian ini dilakukan dalam tiga tahap. Tahap pertama adalah melakukan analisis terhadap dokumen regulasi, baik di tingkat nasional, provinsi maupun Kota Yogyakarta. Adapun regulasi yang dianalisis meliputi Undang-Undang No. 25 Tahun 2009 tentang Pelayanan Publik, Undang-Undang No. 13 Tahun 1998 tentang Kesejahteraan Lanjut Usia, Undang-Undang No. 11 Tahun 2009 tentang Kesejahteraan Sosial, Perda DIY No. 11 Tahun 2015 tentang Lembaga Kesejahteraan Sosial, Keputusan Gubernur DIY No. 282/Kep/2014 tentang Penetapan Pengurusan Komisi Daerah Lanjut Usia, Peraturan Wali Kota Yogyakarta No. 61 Tahun 2013 tentang Pelayanan Rumah Sehat Lansia, Peraturan Wali Kota Yogyakarta No. 69 Tahun 2006 tentang Pembentukan Komisi Kota Lanjut Usia Kota Yogyakarta, Peraturan Wali Kota Yogyakarta No. 11 Tahun 2018 tentang Pedoman Pemberian Asistensi Sosial Bagi Lanjut Usia Terlantar Kota Yogyakarta, dan Keputusan Wali Kota Yogyakarta No. 25 Tahun 2016 tentang Penetapan Daftar Penerima Bantuan Sosial Pemerintah Kota Yogyakarta Tahun Anggaran 2016 dalam Bentuk Uang. Selanjutnya tahap kedua adalah melakukan survei kepada lansia di Desa Sorosutan, Kecamatan Umbulharjo, Kota Yogyakarta. Desa penelitian tersebut dipilih secara purposif dengan pertimbangan bahwa desa tersebut memiliki jumlah lansia terbanyak di Kecamatan Umbulharjo. Sementara itu, pemilihan Kecamatan Umbulaharjo disebabkan oleh alasan yang sama, yaitu jumlah lansia di kecamatan tersebut adalah yang paling banyak dibandingkan dengan kecamatan lainnya di Kota Yogyakarta. Survei dilakukan terhadap 320 lansia yang dipilih secara acak dari populasi (lansia) sebanyak 7.564. Penentuan jumlah sampel dilakukan menggunakan rumus Slovin (Yamane,
1967) Tahap kedua ini ditujukan untuk mengidentifikasi kebutuhan lansia. Kemudian tahap ketiga adalah melakukan pendalaman isu kepada pemangku kepentingan di Kota Yogyakarta untuk memahami program perawatan lansia yang telah dilakukan di Kota Yogyakarta. Sumber informasi untuk tahap ketiga ini adalah Kepala Dinas Kesehatan, staf bagian Lansia Dinas Sosial, Kepala Dinas Pengendalian Penduduk dan KB, Plt. Kepala Dinas Kominfo, dan staf Dinas Dukcapil.

Analisis data yang digunakan untuk tahap pertama adalah dengan melakukan analisis isi terhadap tiap regulasi dan melakukan komparasi antarregulasi tersebut. Analisis untuk tahap kedua dilakukan secara deskriptif, menggunakan tabel tunggal. Sementara itu, analisis tahap ketiga adalah melakukan analisis deskriptif kualitatif untuk mendeskripsikan fakta, opini, dan argumen yang terkait dengan topik penelitian.

\section{Hasil dan Pembahasan}

\section{Regulasi Perawatan Lansia}

Pemerintah telah menetapkan arah kebijakan lanjut usia sebagaimana tertuang di dalam RPJMN 2015-2019. Terdapat dua arah kebijakan yang penting. Pertama, peningkatan pemenuhan hak dasar dan inklusivitas lansia dengan cara meningkatkan advokasi regulasi dan kebijakan di tingkat pusat dan daerah untuk pemenuhan hak dasar lansia serta meningkatkan penyuluhan sosial untuk pendidikan dan kesadaran masyarakat mengenai lingkungan inklusif bagi lansia. Kedua, memperkuat skema perlindungan sosial bagi lansia. Salah satu kata kunci dalam arah kebijakan tersebut adalah pemenuhan hak dasar lansia dan perlindungan sosial bagi lansia. Untuk mewujudkan hal tersebut, perlu dukungan peraturan perundangan yang 
mampu menjadi dasar bagi implementasi kebijakan lansia, baik di tingkat nasional maupun daerah.

Dalam rangka mewujudkan hal tersebut, pemerintah menetapkan Sistem Jaminan Sosial Nasional (SJSN) yang telah disempurnakan bersama Sistem Perlindungan Sosial Nasional (SPSN). Sistem itu kemudian didukung oleh peraturan perundang-undangan dan pendanaan serta sistem Nomor Induk Kependudukan (NIK) yang dapat memberikan perlindungan penuh kepada masyarakat luas secara bertahap (Bappenas, 2015). Dengan demikian, sebenarnya fondasi bagi kebijakan lansia di Indonesia telah cukup kuat.

Sementara itu, regulasi mengenai kesejahteraan lansia telah cukup banyak dikeluarkan pemerintah, baikmelalui peraturan perundang-undangan, peraturan pemerintah, peraturan menteri, maupun peraturan lain yang mengikat untuk menjamin kehidupan dan kesejahteraan lansia. Regulasi tersebut dibuat, salah satunya, untuk mewujudkan adanya pembangunan yang lebih merata dan berkeadilan, melalui sistem jaminan sosial dan kesejahteraan yang disusun, ditata, dan dikembangkan untuk memastikan dan memantapkan pemenuhan hak-hak rakyat pelayanan sosial dasar, tidak terkecuali lansia. Selain itu, regulasi tentang jaminan sosial dan kesejahteraan lansia merupakan salah satu upaya untuk mewujudkan agenda prioritas Nawacita, yaitu inklusivitas penduduk disabilitas dan lansia.

Undang-Undang Nomor 13 Tahun 1998 tentang Kesejahteraan Lansia merupakan kebijakan pertama yang berkaitan dengan lansia di Indonesia. Undang-Undang Nomor 13 Tahun 1998 tersebut ditegaskan melalui Peraturan Pemerintah Nomor 43 Tahun 2004 tentang Pelaksanaan Upaya Peningkatan Kesejahteraan Sosial Lanjut Usia dan dikawal melalui Keputusan Presiden Nomor 52 Tahun 2004 tentang Pembentukan Komisi Nasional Lanjut Usia. Namun, Saputro, dkk. (2015) menyatakan bahwa Undang-Undang Nomor 13 Tahun 1998 tersebut telah saatnya dievaluasi mengingat peraturan tersebut berbeda situasi dengan perkembangan lansia saat ini.

Pemerintah juga secara khusus telah mengeluarkan Undang-Undang Nomor 11 Tahun 2009 tentang Kesejahteraan Sosial untuk menjamin kesejahteraan kaum marginal. Sesuai amanat Undang-Undang Nomor 11 Tahun 2009 tentang Kesejahteraan Sosial, kesejahteraan sosial diartikan sebagai sebagai suatu keadaan terpenuhinya kebutuhan hidup yang layak bagi masyarakat sehingga mampu mengembangkan diri dan dapat melaksanakan fungsi sosialnya yang dapat dilakukan pemerintah, pemerintah daerah, dan masyarakat dalam bentuk pelayanan sosial. Oleh sebab itu, arah kebijakan jaminan sosial dan kesejahteraan diupayakan untuk memenuhi kebutuhan dasar, serta memperkuat upaya jaminan sosial dan kesejahteraan bagi lansia.

Lahirnya Undang-Undang Nomor 13 Tahun 1998 tentang Kesejahteraan Lansia serta Keputusan Presiden Nomor 93/M/2005 tentang Penunjukan dan Keanggotaan Komisi Nasional untuk Lansia (2005-2008), dan peraturan khusus yang diberlakukan untuk mengatasi hal-hal yang berkaitan dengan lansia merupakan bentuk perhatian Pemerintah Indonesia terhadap lansia (Abikusno, 2007). Hal tersebut terlihat dari isi peraturan sebagaimana tentang kesejahteraan lansia kesejahteraan lansia ditunjukkan dalam Tabel 1 berikut. 
Tabel 1 Regulasi tentang Jaminan Sosial dan Kesejahteraan Lansia

\begin{tabular}{|c|c|c|c|}
\hline No & Level & Jenis Peraturan & Isi \\
\hline \multirow[t]{12}{*}{1} & \multirow{12}{*}{$\begin{array}{l}Z_{0 .} \\
\frac{\omega}{0} \\
\frac{D}{2} \\
\underline{D}\end{array}$} & $\begin{array}{l}\text { Undang-Undang Nomor } 32 \text { tahun } 2004 \\
\text { tentang Pemerintah Daerah }\end{array}$ & $\begin{array}{l}\text { Pasal } 2 \text { ayat } 3 \text {, Pasal 13, dan Pasal } 14 \\
\text { Amanat pelaksanaan otonomi daerah } \\
\text { urusan wajib }\end{array}$ \\
\hline & & $\begin{array}{l}\text { Undang-Undang Nomor } 25 \text { Tahun } 2009 \\
\text { tentang Pelayanan Publik }\end{array}$ & $\begin{array}{l}\text { Pasal } 29 \text { ayat } 1 \text { : } \\
\text { Pelayanan pada masyarakat khusus } \\
\text { termasuk lansia }\end{array}$ \\
\hline & & $\begin{array}{l}\text { Undang-Undang Nomor } 33 \text { Tahun } 2004 \\
\text { tentang Perimbangan Keuangan antara } \\
\text { Pemerintah Pusat dan Pemerintah Daerah }\end{array}$ & $\begin{array}{l}\text { Pasal } 70 \text { Ayat 3: } \\
\text { Rincian Belanja Daerah menurut fungsi, } \\
\text { salah satunya untuk perlindungan sosial }\end{array}$ \\
\hline & & $\begin{array}{l}\text { Undang-Undang Nomor } 36 \text { Tahun } 2009 \\
\text { tentang Kesehatan }\end{array}$ & $\begin{array}{l}\text { Pasal } 138 \text { ayat } 1 \text {, Pasal } 138 \text { ayat } 2, \\
\text { Pasal } 140, \\
\text { Upaya pemeliharaan kesehatan dan } \\
\text { penyediaan fasilitas pelayanan kesehatan } \\
\text { bagi lanjut usia }\end{array}$ \\
\hline & & $\begin{array}{l}\text { Undang-Undang Nomor } 13 \text { Tahun } 1998 \\
\text { tentang Kesejahteraan Lanjut Usia }\end{array}$ & $\begin{array}{l}\text { Pasal } 5 \text { ayat } 2 \text {, Pasal } 14 \text { ayat 2, Pasal } 15 \\
\text { ayat } 2 \text {, Pasal } 16 \text { ayat } 2 \text {, Pasal } 17 \text { ayat } 2 \\
\text { Berbagai bentuk penghormatan dan } \\
\text { penghargaan kepada lanjut usia }\end{array}$ \\
\hline & & $\begin{array}{l}\text { Undang-Undang Nomor } 11 \text { Tahun } 2009 \\
\text { tentang Kesejahteraan Sosial }\end{array}$ & $\begin{array}{l}\text { Pasal } 9 \text { ayat } 1 \text { dan } 3 \text {, Pasal } 12 \text {, pasal } 17 \\
\text { ayat } 6 \\
\text { Jaminan sosial dan pemberdayaan sosial }\end{array}$ \\
\hline & & $\begin{array}{l}\text { Peraturan Menteri Sosial Nomor } 184 \text { Tahun } \\
2011 \text { tentang Lembaga Kesejahteraan } \\
\text { Sosial }\end{array}$ & $\begin{array}{l}\text { Pasal 4, Pasal 5, Pasal } 38 \text { ayat } 2 \\
\text { Fungsi dan peran Lembaga } \\
\text { Kesejahteraan Sosial (LKS) dalam } \\
\text { penyelenggaraan kesejahteraan sosial }\end{array}$ \\
\hline & & $\begin{array}{l}\text { Peraturan Menteri Sosial Republik } \\
\text { Indonesia Nomor } 19 \text { Tahun } 2012 \text { tentang } \\
\text { Pedoman Pelayanan Sosial Lanjut Usia }\end{array}$ & $\begin{array}{l}\text { Pasal 2, Pasal } 5 \text {, Pasal } 17 \text {, pasal } 21 \text { a } \\
\text { dan b, pasal } 22 \text { ayat } 1 \text { dan } 2 \text {, pasal } 23 \text {, } \\
\text { a-d, Pasal } 28 \text { ayat } 1 \\
\text { Jenis dan pelaksanaan pedoman } \\
\text { pelayanan lanjut usia }\end{array}$ \\
\hline & & $\begin{array}{l}\text { Peraturan Menteri Kesehatan Nomor } \\
65 \text { Tahun } 2013 \text { tentang Pedoman } \\
\text { Pelaksanaan dan Pembinaan } \\
\text { Pemberdayaan Masyarakat Bidang } \\
\text { Kesehatan }\end{array}$ & $\begin{array}{l}\text { Bab II bagian A, Pasal } 3 \\
\text { Pemberdayaan masyarakat dan } \\
\text { kelompok dalam meningkatkan } \\
\text { kesejahteraan di bidang kesehatan }\end{array}$ \\
\hline & & $\begin{array}{l}\text { Peraturan Menteri Sosial Nomor } 12 \text { Tahun } \\
2012 \text { tentang Pelaksanaan Asistensi Sosial } \\
\text { Lanjut Usia Telantar }\end{array}$ & $\begin{array}{l}\text { Tata pelaksanaan program Asistensi } \\
\text { Sosial Lanjut Usia Telantar }\end{array}$ \\
\hline & & $\begin{array}{l}\text { Peraturan Menteri Sosial RI Nomor } 12 \\
\text { Tahun } 2013 \text { tentang Program ASLUT }\end{array}$ & $\begin{array}{l}\text { Pasal 1, Pasal 2, Pasal 17, Pasal } 21 \\
\text { Tujuan dan pelaksanaan Program } \\
\text { Asistensi Sosial Lanjut Usia Telantar } \\
\text { (ASLUT) }\end{array}$ \\
\hline & & $\begin{array}{l}\text { Peraturan Menteri Dalam Negeri Nomor } \\
60 \text { Tahun } 2008 \text { tentang Pedoman } \\
\text { Pembentukan Komisi Daerah Lanjut Usia } \\
\text { dan Pemberdayaan Masyarakat dalam } \\
\text { Penanganan Lanjut Usia di Daerah }\end{array}$ & $\begin{array}{l}\text { Pasal 1, Pasal } 2 \text { ayat 1, Pasal } 2 \text { ayat 2, } \\
\text { Pasal 5, Pasal } 6 \\
\text { Amanah pembentukan komisi daerah } \\
\text { lanjut usia sebagai upaya penanganan } \\
\text { masalah lanjut usia }\end{array}$ \\
\hline
\end{tabular}


Peraturan Menteri Kesehatan RI Nomor 25 tahun 2016 tentang Rencana Aksi Nasional Kesehatan Lansia Tahun 2016-2019

Peraturan Menteri Sosial Republik Indonesia Nomor 4 Tahun 2017 Tentang Pedoman Pengembangan Kawasan Ramah Lanjut Usia

Peraturan Menteri Sosial Nomor 1 Tahun 2017 tentang Pedoman Penghargaan Kesejahteraan Sosial Lanjut Usia

Peraturan Menteri Sosial Republik Indonesia Nomor 5 Tahun 2018 tentang Standar Nasional Rehabilitasi Sosial Lanjut Usia

Peraturan Menteri Sosial Republik Indonesia Nomor 22 Tahun 2016 tentang Standar Nasional Lembaga Kesejahteraan Sosial

Peraturan Menteri Keuangan RI Nomor 254 tahun 2015 tentang Belanja Bantuan Sosial pada Kementerian Negara/Lembaga

Peraturan Pemerintah Nomor 58 Tahun 2005 tentang Pengelolaan Keuangan Daerah

Peraturan Pemerintah Nomor 38 Tahun 2007 tentang Pembagian Urusan Pemerintahan antara Pemerintah, Pemeritah Daerah Provinsi, dan Pemerintah daerah Kabupaten/Kota

Peraturan Pemerintah Nomor 43 Tahun 2004 tentang Pelaksanaan Upaya Peningkatan Kesejahteraan Sosial Lanjut Usia

Peraturan Pemerintah Nomor 39 Tahun 2012 tentang Penyelenggaraan Kesejahteraan Sosial

Keputusan Presiden Nomor 52 Tahun 2004 Komisi Nasional Lanjut Usia

Peraturan Menteri Sosial Republik Indonesia Nomor 129 / HUK / 2008 tentang Standar Pelayanan Minimal (SPM) Bidang Sosial Daerah Provinsi dan Daerah Kabupaten/Kota

Peraturan Menteri Kesehatan Republik Indonesia Nomor 67 Tahun 2015 tentang Penyelenggaraan Pelayanan Kesehatan Lanjut Usia di Pusat Kesehatan Masyarakat

\section{Pasal 1, Pasal 2}

Pengaturan dan ruang lingkup Rencana Aksi Nasional Kesehatan Lanjut Usia Tahun 2016-2019

Pasal 3, Pasal 5,

Tujuan dan kriteria dalam pengembangan Kawasan Ramah Lanjut Usia

\section{Pasal 3, Pasal 5 ayat 1}

Tujuan dan sasaran pemberian penghargaan kesejahteraan sosial lanjut usia

\section{Pasal 6, Pasal 11, Pasal 47, Pasal 48} ayat 1

Tujuan, bentuk, dan standar sarana prasarana rehabilittasi sosial lanjut usia

\section{Lampiran B:}

Upaya mewujudkan LKS yang memenuhi standar/spesifikasi teknis sebagai pelaku penyelenggaraan kesejahteraan sosial

Pasal 4, Pasal 6 ayat 1, Pasal 6 Ayat 7 Anggaran Belanja dan tujuan penggunaan, dan bentuk dari bantuan social

\section{Pasal 26 Ayat 2, Pasal 116}

Belanja penyelenggaraan urusan wajib

\section{Pasal 3, Pasal 7 Ayat 2}

Berbagai urusan pemerintahan yang diserahkan kepada daerah termasuk pemberdayaan masyarakat dan sosial.

Pasal 7, Pasal 8 Ayat 2, Pasal 9 Ayat 2, Pasal 16 Ayat 2, Pasal 17 Ayat 2, Pasal 34 Ayat 2, Pasal 35 Ayat 2, Pasal 36 Ayat 2 Berbagai pelayanan terhadap lanjut usia

Pasal 37, dan Bab III Jaminan Sosial Pasal 10 ayat 1-2

Sarana dan prasarana Penyelenggaraan Kesejahteraan Sosial

\section{Pasal 3, Pasal 20}

Pembentukan Komisi Nasional Lanjut Usia dan amanah pembentukan Komisi Daerah Lanjut Usia

\section{Pasal 4 ayat 1 (d)}

Pelayanan dalam rangka penanggulangan masalah sosial yang bersifat lintas kabupaten/kota

\section{Pasal 3, Pasal 4 Ayat 2, Pasal 6 Ayat 2,} Pasal 10 Jenis-jenis pelayanan kesehatan Lanjut Usia di Puskesmas 
Perawatan Lansia: Menerjemahkan Peraturan Nasional

ke dalam Program Lokal di Kota Yogyakarta

\begin{tabular}{ll}
\hline 2 & Peraturan Daerah Daerah Istimewa \\
Yogyakarta Nomor 6 Tahun 2008 tentang \\
Organisasi dan Tata Kerja
\end{tabular}

Peraturan Daerah Daerah Istimewa

Yogyakarta Nomor 5 Tahun 2014 tentang

Pelayanan Publik

\ָ.

Peraturan Daerah Daerah Istimewa

Yogyakarta Nomor 11 Tahun 2015 tentang

Lembaga Kesejahteraan Sosial
Pasal 29, Pasal 30 Ayat 2

Fungsi, peran, dan bidang Dinas Sosial dalam pelayanan kesejahteraan masyarakat termasuk untuk penduduk lanjut usia.

Pasal 24 Ayat 1, Pasal 25, Pasal 34, Standar pelayanan dalam memenuhi kebutuhan masyarakat umum dan masyarakat khusus termasuk lanjut usia

Pasal 10, Pasal 11, Pasal 12, Pasal 13

Fungsi dari LKS, jenis pelayanan

kesejahteraan di tingkat provinsi, dan kegiatan dalam kesejahteraan sosial di wilayah DIY

Keputusan Gubernur Daerah Istimewa

Yogyakarta No. 282/Kep/2014 tentang

Penetapan susunan pengurus Koda

Lansia tingkat Provinsi periode 2014-

Penetapan Pengurus Komisi Daerah Lanjut 2017.

Usia Provinsi DIY periode 2014 - 2017

3 Peraturan Wali Kota Yogyakarta Nomor

61 Tahun 2013 tentang Pelayanan Rumah

Sehat Lansia di Kota Yogyakarta

Peraturan Wali Kota Yogyakarta Nomor 46 Tahun 2012 tentang Pembentukan Susunan, Kedudukan, Fungsi dan Rincian Tugas Unit Pelaksana Teknis Penyelenggara Jaminan Kesehatan Daerah dan Pusat Kesehatan Masyarakat pada Dinas Kesehatan Kota Yogyakarta

Peraturan Wali Kota Yogyakarta Nomor 69 tahun 2006 tentang Pembentukan Komisi Kota Lanjut Usia Kota Yogyakarta

Peraturan Wali Kota Yogyakarta Nomor 45 Tahun 2008 tentang Pembentukan Emergency Medical Services System (EMSS) di Wilayah Kota Yogyakarta

Peraturan Wali Kota Yogyakarta Nomor 11 Tahun 2018 tentang Pedoman Pemberian Asistensi Sosial bagi Lanjut Usia Terlantar Kota Yogyakarta

Peraturan Daerah Kota Yogyakarta Nomor 2 Tahun 2008 tentang izin Penyelenggaraan Sarana Kesehatan dan Izin Tenaga Kesehatan

Keputusan Wali Kota Yogyakarta Nomor 25 Tahun 2016 tentang Penetapan Daftar Penerima Bantuan Sosial Pemerintah Kota Yogyakarta Tahun Anggaran 2016 dalam Bentuk Uang

\section{Pasal 2, Pasal 3, Pasal 6}

Maksud, tujuan, dan cakupan pelayanan

Rumah Sehat Lansia (Rusela) adalah untuk menaikkan derajat kesehatan bagi lanjut usia di Kota Yogyakarta.

Pasal 3, Pasal 4 Ayat 1, Pasal 8 Ayat 1, Pasal 12 Ayat 1

Tugas Unit Pelaksana Teknis dalam bidang kesehatan di Kota Yogyakarta
Maksud dan tujuan dari pembentukan komisi kota lanjut usia Kota Yogyakarta

Pasal 1 Poin 7, Pasal 2 Pasal 3

Pengertian, maksud, dan tujuan, (EMSS) dalam bidang pelayanan gawat darurat untuk masyarakat.

Pasal 2 Ayat 1 dan 2, Pasal 4, Pasal 5 Ayat 1

Sistem pemberian bantuan dalam bentuk Asistensi Sosial Lanjut Usia Terlantar (ASLUT) Kota Yogyakarta.

\section{Pasal 3, Pasal 6, Pasal 7 Ayat 1}

Jenis dan peran dari sarana kesehatan dan tenaga kesehatan.

Berdasarkan Keputusan Wali Kota Yogyakarta Nomor 25 Tahun 2016 terdapat beberapa Kelompok Usaha Ekonomi Produktif Lanjut Usia Potensial (UEP-LU) yang menerima bantuan sosial
Emergency Medical Services System

Sumber: Hasil Telaah Dokumen Kebijakan, 2018 
Berdasarkan sudut pandang normatif, regulasi pada tingkat nasional cukup menjadi landasan bagi program pelayanan dan perawatan lansia untuk tingkat daerah provinsi dan kabupaten/kota. Hal ini ditunjukkan dari banyaknya regulasi yang mengatur aspek kesehatan, sosial, dan ekonomi. Salah satu regulasi tersebut adalah Undang-Undang Nomor 11 Tahun 2009 tentang Kesejahteraan Sosial yang hanya memuat sedikit substansi yang berkaitan dengan lansia, yaitu mengenai jaminan sosial bagi lansia yang tercantum pada pasal 9 ayat 1-3. Isi dari pasal tersebut adalah sebagai berikut.

1. Jaminan sosial dimaksudkan untuk

a) menjamin fakir miskin, anak yatim piatu terlantar, lanjut usia terlantar, penyandang cacat fisik, cacat mental, cacat fisik dan mental, eks penderita penyakit kronis yang mengalami masalah ketidakmampuan sosial ekonomi agar kebutuhan dasarnya terpenuhi,

b) menghargai pejuang, perintis kemerdekaan, dan keluarga pahlawan atas jasa-jasanya.

2. Jaminan sosial sebagaimana dimaksud pada ayat (1) huruf a diberikan dalam bentuk asuransi kesejahteraan sosial dan bantuan langsung berkelanjutan.

3. Jaminan sosial sebagaimana dimaksud pada ayat (1) huruf b diberikan dalam bentuk tunjangan berkelanjutan. Peningkatan kegiatan keagamaan sesuai dengan agama dan keyakinannya masing-masing.

Pada aspek ekonomi, pemerintah telah mengeluarkan regulasi sebagai dasar hukum pelaksanaan investasi sosial melalui Usaha Ekonomi Produktif (UEP). Pemerintah berupaya untuk memberikan akses dan pelayanan kesempatan kerja bagi lanjut usia potensial, baik pada sektor formal maupun sektor nonformal. Hal ini berarti bahwa pemerintah memberikan kesempatan bagi lansia untuk mengembangkan dan menyalurkan potensinya melalui peluang kesempatan kerja. Dengan demikian, secara keseluruhan, regulasi pemerintah mengenai perlindungan dan jaminan ekonomi bagi lansia telah cukup memadai.

Pada aspek kesehatan, pemerintah melalui Undang-Undang Nomor 36 Tahun 2009 tentang Kesehatan menjamin upaya peningkatan dan pemeliharaan kesehatan dengan prinsip nondiskriminasi. Salah satu komitmen pemerintah adalah memberikan keringanan biaya kesehatan yang diberikan kepada lansia yang kurang mampu untuk mendapatkan pelayanan kesehatan sesuai dengan peraturan perundangan. Dengan demikian, secara keseluruhan, regulasi pemerintah telah mengakomodasi perlindungan dan jaminan kesehatan bagi lansia.

Dilihat dari aspek lainnya, seperti sarana dan prasarana, serta administrasi dan informasi, pemerintah telah mengeluarkan regulasi, yaitu Peraturan Pemerintah Republik Indonesia Nomor 4 Tahun 2017 dan Undang-Undang Republik Indonesia Nomor 11 Tahun 2009 tentang Kesejahteraan Sosial. Dalam undang-undang tersebut, pasal 17 ayat 6 menyebutkan bahwa pelayanan yang diberikan bermaksud memberikan aksesibilitas kepada lansia, terutama di tempat-tempat umum yang dapat menghambat mobilitas lanjut usia. Sementara itu, pasal berikutnya, yaitu pasal18 ayat 1 , mengatur ketentuan pelayanan administrasi bagi lansia yang meliputi,

1. memperoleh Kartu Tanda Penduduk (KTP) seumur hidup;

2. melaksanakan kewajibannya membayar pajak negara;

3. memperoleh pelayanan kesehatan pada sarana kesehatan milik pemerintah;

4. melaksanakan pernikahan; dan 


\section{Perawatan Lansia: Menerjemahkan Peraturan Nasional \\ ke dalam Program Lokal di Kota Yogyakarta}

5. melaksanakan kegiatan lain yang berkenaan dengan pelayanan umum.

Namun, secara khusus, UU No. 13 Tahun 1998 perlu direvisi dalam rangka penyempurnaan untuk merespons perubahan konteks yang terjadi selama dua puluh tahun. Hal ini senada dengan hasil kajian yang dilakukan oleh Kantor Menteri Koordinator Bidang Pembangunan Manusia dan Kebudayaan (2015) yang menyarankan pemerintah merevisi undang-undang tersebut.

\section{Kebijakan Lansia di Level Lokal}

Regulasi yang dikeluarkan pemerintah pusat untuk mendorong inklusivitas bagi lansia telah menjadi amanat bagi pemerintah daerah di level daerah/kota. Wijaya dan Suparto (dalam Pasolong, 2007: 56) mengatakan bahwa implementasi adalah proses mentransformasikan suatu rencana ke dalam praktik. Dalam hal ini, pemerintah daerah dituntut untuk mengimplementasikan kebijakan yang berkaitan dengan jaminan sosial dan kesejahteraan ke dalam program pemerintah.

Mengacu pada Peraturan Menteri Dalam Negeri Nomor 60 Tahun 2008 tentang Pedoman Pembentukan Komisi Daerah Lanjut Usia (Lampiran Peraturan Menteri Nomor 25 Tahun 2016), pemerintah daerah provinsi melalui Keputusan Gubernur Daerah Istimewa Yogyakarta Nomor 282/Kep/2014 tentang Penetapan Pengurus Komisi Daerah Lanjut Usia Provinsi DIY Periode 2014-2017 telah menetapkan susunan pengurus Komisi Daerah Lansia di DIY. Hal tersebut konsisten diterapkan oleh Pemerintah Kota Yogyakarta yang mengeluarkan Peraturan Wali Kota Yogyakarta Nomor 69 Tahun 2006 tentang Pembentukan Komisi Kota Lanjut Usia Kota Yogyakarta. Konsekuensi dari adanya komisi ini adalah komitmen pemerintah daerah untuk mengarahkan, membimbing, dan menciptakan suasana yang menunjang terlaksananya upaya peningkatan kesejahteraan sosial lanjut usia (Silviany, 2015). Dalam hal ini, Komisi Kota Lanjut Usia di DIY dapat bertindak sebagai inisiator dalam merumuskan program-program berbasis kesejahteraan lansia.

Berbagai bentuk program untuk lansia di Kota Yogyakarta diimplementasikan dengan strategi pemberdayaan, partisipasi, kemitraan, desentralisasi, serta membangun dan mengembangkan partisipasi dan advokasi atas dasar kesetiakawanan sosial (Bappenas, 2015). Upaya-upaya untuk mendorong terwujudnya program kesejahteraan lansia di Kota Yogyakarta merupakan program dan kewenangan yang dijalankan oleh Dinas Kesehatan dan Dinas Sosial Kota Yogyakarta.

Hasil penelitian Khotimah, dkk. (2016) memaparkan bahwa permasalahan yang dialami oleh lansia di Kota Yogyakarta dapat dikategorikan menjadi lima dimensi berikut. Pertama adalah fisik, yang meliputi perubahan fisik, seperti penurunan kondisi fisik, pendengaran dan penglihatan yang berkurang, kulit keriput, serta rambut yang memutih. Kedua adalah psikologis, yang meliputi terjadinya gangguan persepsi, gangguan saat berkomunikasi, penurunan konsentrasi, penurunan daya ingat, mengalami perubahan sikap dan perilaku, serta perubahan pada aspek emosi dan perasaan. Ketiga adalah mental spiritual, yang meliputi seberapa percayanya lansia kepada Tuhan dan agama, bagaimana peran keluarga dalam memperkuat keimanan. Keempat adalah sosial kemasyarakatan karena sebagian besar lansia cenderung mengalami perubahan sosial, dalam hal ini masyarakat serta keluarga sangat berperan penting untuk melakukan upaya membangun kepedulian antara sesama lansia dan masyarakat dengan cara memaksimalkan aktivitas lansia dalam kegiatan-kegiatan, 
seperti arisan, pengajian, kerajinan, serta kegiatan-kegiatan seni budaya. Kelima adalah pengembangan potensi karena lansia cenderung diam di rumah atau mengerjakan hal-hal sederhana, seperti menunggu cucu.

Berdasarkan hasil survei, permasalahan lansia di Kota Yogyakarta dapat dikelompokkan menjadi tiga isu utama, yaitu kesehatan, sosial, dan ekonomi. Hal tersebut sesuai dengan implementasi program untuk lansia di Kota Yogyakarta yang secara garis besar memprioritaskan pada isu utama tersebut.. Isu utama tersebut adalah isu kesehatan yang pelaksanaan programnya dilakukan oleh Dinas Kesehatan, serta isu sosial dan ekonomi yang programnya dilaksanakan oleh Dinas Sosial Kota Yogyakarta. Program-program tersebut dimaksudkan untuk mengurangi permasalahan lansia di Kota Yogyakarta. Hal ini dapat dilihat dari diterbitkannya Peraturan Daerah Nomor 6 Tahun 2008 tentang Organisasi dan Tata Kerja Dinas Daerah provinsi DIY. Dalam perda tersebut, diamanatkan bahwa Dinas Sosial merupakan penanggung jawab permasalahan lansia. Peraturan tersebut merupakan turunan dari amanat yang tercantum pada UndangUndang Nomor 32 Tahun 2004 tentang Pemerintah Daerah.

Permasalahan kesehatan, sosial, dan ekonomi lansia sebagaimana telah dijelaskan merupakan permasalahan yang banyak dialami, baik oleh lansia, keluarga lansia, masyarakat maupun pemerintah. Hal ini sesuai dengan pernyataan Astuti, dkk. (2016) yang menyatakan bahwa masalah kesehatan merupakan masalah yang paling sering dialami pada lansia di Indonesia. Selain tidak memiliki jaminan kesehatan maupun dana pensiun, banyak lansia belum tersentuh program-program pemerintah.

Kemudian Pemerintah Kota Yogyakarta berupayauntuk meningkatkan kualitas kesehatan lansia dengan melakukan peningkatan akses dan kualitas pelayanan dasar serta rujukan dengan mengembangkan pelayanan perawatan pada lansia. Adapun program-program yang telah diimplementasi Pemerintah Kota Yogyakarta untuk meningkatkan kualitas kesehatan lansia oleh Dinas Kesehatan Kota Yogyakarta ditunjukkan dalam Tabel 2 berikut.

\section{Tabel 2 Program Kesehatan Lansia di Kota Yogyakarta}

\begin{tabular}{cl}
\hline No & \multicolumn{1}{c}{ Program Kesehatan } \\
\hline 1 & $\begin{array}{l}\text { Akses dan Mutu Pelayanan Kesehatan } \\
\text { a. } \\
\text { b. Sawat jalan dan kunjungan gangguan jiwa di Puskesmas Kota Yogyakarta } \\
\text { Level 1 Kota Yogyakarta }\end{array}$ \\
\hline 2 & $\begin{array}{l}\text { Meningkatkan sediaan farmasi dan alat kesehatan yang memenuhi standar dan terjangkau } \\
\text { oleh masyarakat dengan Indikator Kerja Utama "Persentase Ketersediaan Obat dan Vaksin" }\end{array}$ \\
\hline 3 & $\begin{array}{l}\text { Menetapkan standar pelayanan minimal: pelayanan kesehatan dasar, pelayanan kesehatan } \\
\text { rujukan, penyelidikan epidemiologi dan penanggulangan KLB, serta promosi kesehatan dan } \\
\text { pemberdayaan masyarakat }\end{array}$ \\
\hline & $\begin{array}{l}\text { Upaya inovasi kesehatan } \\
\text { a. Yogyakarta Emergency Services 118 (Peraturan Wali Kota Yogyakarta Nomor 45 Tahun }\end{array}$ \\
$\quad \begin{array}{l}\text { 2008 tentang Pembentukan Emergency Medical Services System (EMSS) di Wilayah } \\
\text { Kota Yogyakarta) }\end{array}$ \\
b. Upaya promosi kesehatan di ruang tunggu puskesmas
\end{tabular}

Sumber: Hasil Olah Data, 2018 
Berdasarkan program-program tersebut dan apabila dibandingkan dengan regulasi tentang perlindungan dan jaminan kesehatan lansia di tingkat pusat, Pemerintah Kota Yogyakarta telah mengimplementasi program denganlebih baik. Pemerintah Kota Yogyakarta melalui Dinas Kesehatan telah memberikan perlindungan dan jaminan kesehatan bagi lansia di Kota Yogyakarta sesuai dengan prioritas kebijakan yang telah diamanatkan, baik oleh peraturan perundangan maupun sesuai dengan kebijakan yang diperlukan untuk meningkatkan kualitas kesehatan lansia di Kota Yogyakarta. Dinas Kesehatan mengungkapkan berbagai layanan selain Rusela yang dapat dimanfaatkan oleh lansia, seperti layanan gawat darurat (YES 118 dan PVC 119) yang diatur dalam Peraturan Wali Kota Yogyakarta Nomor 45 Tahun 2008 tentang Pembentukan Emergency Medical Services System (EMSS) di Wilayah Kota Yogyakarta. Di samping itu, ada pula pelayanan psikologis di puskesmas dan penerapan sistem puskesmas santun lansia yang diatur dengan Peraturan Wali Kota Yogyakarta Nomor 46 Tahun 2012 tentang Pembentukan Susunan, Kedudukan, Fungsi dan Rincian Tugas Unit Pelaksana Teknis Penyelenggara Jaminan Kesehatan Daerah dan Pusat Kesehatan Masyarakat Pada Dinas Kesehatan Kota Yogyakarta.

Namun, sumber daya manusia, anggaran, infrastruktur, dan lingkungan sosial budaya untuk mendukung kesejahteraan lansia di DIY masih perlu ditingkatkan. Fasilitas publik di lingkungan publik belum ramah lansia dan aksesibilitas pada pusat-pusat pelayanan lansia juga masih terbatas (Yanuardi, dkk., 2017). Berdasarkan hasil wawancara dengan salah satu informan Dinas Kesehatan, tampak bahwa peran puskesmas dalam pelayanan psikologis masih belum optimal karena masih banyak lansia belum mengetahui keberadaan pelayanan psikologis di puskesmas meskipun seluruh puskesmas di Kota Yogyakarta memiliki pelayanan konseling psikologis.

"Kota Yogyakarta memiliki layanan gawat darurat berupa panggilan 118 atau 119 yang terhubung dengan ambulans dan dokter 24 jam. Layanan konseling psikologis terdapat di seluruh puskesmas di Kota Yogyakarta, namun ini menjadi kendala karena banyak masyarakat yang tidak mengetahui fungsi layanan ini. Seluruh puskesmas di Kota Yogyakarta telah menerapkan kebijakan santun lansia, yakni membedakan pendaftaran, antrean, dan layanan untuk lansia."

Pelayanan Rusela adalah wujud implementasi program pada bidang kesehatan. Program ini diatur dalam Peraturan Wali Kota Yogyakarta Nomor 61 Tahun 2013 tentang Pelayanan Rumah Sehat Lansia di Kota Yogyakarta. Peraturan tersebut mengacu pada Peraturan Daerah Daerah Istimewa Yogyakarta Nomor 5 Tahun 2014 tentang Pelayanan Publik pada Level Provinsi, Undang-Undang Nomor 25 Tahun 2009 tentang Pelayanan Publik, dan UndangUndang Nomor 36 Tahun 2009 tentang Kesehatan pada Level Nasional. Di Rusela, terdapat berbagai kegiatan yang dapat meningkatkan kesehatan dan interaksi sosial lansia, seperti penyuluhan kesehatan, cek kesehatan, dan senam lansia. Kelemahan dari program ini adalah belum dapat menjangkau sepenuhnya lansia di Kota Yogyakarta karena hanya terdapat satu Rusela di Kota Yogyakarta. Oleh karena itu, kegiatan lebih sering diadakan untuk lansia setempat, yakni lansia yang berada di Kelurahan Sorosutan. Hal tersebut seperti yang dikemukakan oleh Kepala Dinas Kesehatan Kota Yogyakarta berikut ini. 
"Kegiatan di Rusela rutin diadakan setiap Rabu dan Sabtu, Rabu untuk penyuluhan dari dinas atau puskesmas dan Sabtu untuk senam lansia. Terkadang juga ada kegiatan dari luar pemerintah, seperti mahasiswa atau komunitas tertentu untuk sosialisasi kepada lansia."

Hasil survei menunjukkan bahwa 35 persen lansia membutuhkan kegiatan sosial dan 40 persen di antaranya membutuhkan perkumpulan lansia. Kebutuhan tersebut terkait dengan permasalahan yang dihadapi oleh sebagian besar lansia, yaitu kesepian (33 persen). Permasalahan dan kebutuhan tersebut sekaligus menggambarkan bahwa lansia membutuhkan rekan sebaya (peer group). Rusela merupakan program yang dapat mengakomodasi permasalahan dan kebutuhan lansia tersebut.

Sementara itu, dilihat dari aspek sosial, Pemerintah Kota Yogyakarta melalui Dinas Sosial terus berupaya untuk memberikan jaminan sosial dan kesejahteraan bagi lansia. Kesadaran bersama bahwa masalah sosial pada lansia dapat disebabkan oleh perubahan pola kehidupan, sistem kekeluargaan, nilai sosial ketelantaran, korban tindak kekerasan, serta social exclusion harus ditumbuhkan (Astuti, dkk., 2016). Oleh karena itu, hubungan sosial kemasyarakatan lansia perlu dibangun dengan kreatif di lingkup yang masih dapat diakses oleh lansia (BKKBN, 2014).

Dalam merespons permasalahan sosial dan ekonomi lansia, Pemerintah Kota Yogyakarta membuat program-program berperspektif jaminan sosial dan kesejahteraan ekonomi untuk meningkatkan kualitas kehidupan sosial lansia di Kota Yogyakarta. Adapun program yang dilaksanakan oleh Pemerintah Kota Yogyakarta melalui Dinas Sosial, di antaranya, adalah 1) Program Asistensi Sosial Lanjut Usia Terlantar (ASLUT); 2) Pendampingan dan Perawatan Sosial Lanjut Usia di Rumah (home care); 3) Penanganan Lanjut Usia dalam Situasi Darurat; serta 4) Usaha Ekonomi Produktif (UEP) Lanjut Usia. Tabel 3 berikut menyajikan program sosial lansia di Kota Yogyakarta.

Dibandingkan dengan regulasi terkait jaminan sosial dan kesejahteraan, programprogram yang dikeluarkan oleh Pemerintah Kota Yogyakarta untuk menangani permasalahan sosial dan ekonomi dirasa telah cukup memadai. Hal ini karena secara keseluruhan, amanat perundang-undangan tentang jaminan sosial dan kesejahteraan telah diimplementasi oleh Pemerintah Kota Yogyakarta. Jenis program kesejahteraan lansia di DIY merujuk pada peraturan perundangan pemerintah pusat yang

Tabel 3 Program Sosial dan Ekonomi Lansia di Kota Yogyakarta

\begin{tabular}{ll}
\hline \multicolumn{1}{c}{ ASLUT } & \multicolumn{1}{c}{ Home Care } \\
\hline $\begin{array}{l}\text { Asistensi sosial untuk lanjut usia terlantar. } \\
\text { Dimungkinkan partisipasi masyarakat setempat } \\
\text { untuk lansia terlantar }\end{array}$ & $\begin{array}{l}\text { Pemenuhan kebutuhan dasar dan } \\
\text { pendampingan lansia terlantar/hidup } \\
\text { sendiri di rumah }\end{array}$ \\
\hline \multicolumn{1}{c}{ Reguler Panti } & \multicolumn{1}{c}{ UEP } \\
\hline $\begin{array}{l}\text { Pemenuhan kebutuhan dasar lanjut usia yang } \\
\text { tinggal di panti }\end{array}$ & $\begin{array}{l}\text { Peningkatan penghasilan dan } \\
\text { pendapatan lanjut usia yang masih dapat } \\
\text { produktif }\end{array}$ \\
\hline
\end{tabular}

Sumber: Hasil Olah Data, 2018 
dilakukan dalam bentuk pelayanan lansia di Balai Pelayanan Sosial Tresna Werdha (BPSTW) untuk memberikan day care service dan trauma service serta pelayanan kesejahteraan lansia berbasis masyarakat yang didanai APBN/APBD, yaitu ASLUT, jaminan sosial lanjut usia (JSLU), UEP, home care, day care dan family support (Yanuardi, dkk., 2017).

Program asistensi sosial lanjut usia terlantar (ASLUT) pada level kota diatur dalam Peraturan Wali Kota Yogyakarta Nomor 11 Tahun 2018 tentang Pedoman Pemberian Asistensi Sosial Bagi Lanjut Usia Terlantar Kota Yogyakarta. Program ASLUT dimaksudkan untuk memberikan pendampingan dan perlindungan sosial lansia supaya memberi kemudahan bagi lansia tidak potensial agar dapat mewujudkan taraf hidup yang wajar. Program ini sesuai dengan Undang-Undang Nomor 13 Tahun 1998 tentang Kesejahteraan Sosial Lansia, Peraturan Menteri sosial RI Nomor 12 Tahun 2013 tentang Program Asistensi Sosial Lanjut Usia Terlantar, Peraturan Menteri Sosial Republik Indonesia Nomor 129/HUK/2008 tentang Standar Pelayanan Minimal (SPM) Bidang Sosial Daerah Provinsi dan Daerah Kabupaten/Kota pasal 4 ayat $1(\mathrm{~d})$, dan Peraturan Pemerintah Republik Indonesia Nomor 39 Tahun 2012 tentang Penyelenggaraan Kesejahteraan Sosial BAB III Jaminan Sosial pasal 10 ayat 1-2. Sementara itu, pedoman pelaksanaan ASLUT telah diatur melalui Peraturan Menteri Sosial Nomor 12 Tahun 2012 tentang Pelaksanaan Asistensi Sosial Lanjut Usia Telantar.

Penanganan lanjut usia dalam situasi darurat yang dijalankan Pemerintah Kota Yogyakarta sesuai dengan regulasi pemerintah, yaitu Peraturan Menteri Sosial Republik Indonesia Nomor 19 Tahun 2012 tentang Pedoman Pelayanan Sosial Lanjut
Usia pasal 20 ayat 1 dan 2, pasal 21 a dan b, pasal 22 ayat 1 dan 2, serta pasal 23 a-d. Pelayanan sosial kedaruratan lanjut usia dimaksudkan sebagai tindakan yang mendesak harus dilakukan dengan melakukan identifikasi masalah dan kebutuhan lanjut usia, serta merumuskan mekanisme pelaksanaan kegiatan dan rujukan. Staf di Dinas Sosial Kota Yogyakarta menyebutkan bahwa penanganannya dilakukan dengan bantuan Tenaga Kesejahteraan Sosial Kecamatan (TKSK) sebagai pihak yang mengidentifikasi permasalahan di lapangan. Berikut adalah kutipan wawancaranya,

"Dahulu TKSK bernama Maskot, saat
ini disebut Tenaga Kesejahteraan
Sosial karena sesuai dengan tugasnya
dalam membantu Dinas Sosial untuk
mengidentifikasi permasalahan
kesejahteraan sosial secara langsung di
lapangan."

Hasil survei menunjukkan bahwa lansia juga membutuhkan dukungan ekonomi. Hal ini ditunjukkan dengan adanya 64 persen lansia (yang pada umumnya adalah perempuan) tidak bekerja. Meskipun sebenarnya anggota keluarga memiliki tanggung jawab untuk menafkahi anggota keluarga yang berusia lanjut, faktanya menunjukkan bahwa tidak semua keluarga mampu melakukannya. Untuk itu, peran pemerintah menjadi sangat penting. Salah satu program yang dilakukan oleh Pemerintah Kota Yogyakarta adalah program usaha ekonomi produktif (UEP).

Program Usaha Ekonomi Produktif (UEP) di Kota Yogyakarta merupakan serangkaian kegiatan yang ditujukan untuk meningkatkan kemampuan dalam mengakses sumber daya ekonomi, meningkatkan kemampuan usaha ekonomi, meningkatkan produktivitas kerja, serta 
meningkatkan penghasilan, tabungan, dan menciptakan kemitraan usaha yang saling menguntungkan (Rachmiyati, 2011). Secara ideal, program ini diharapkan mampu membantu lansia memenuhi kebutuhan ekonominya. Akan tetapi, pelaksanaannya masih belum dapat berjalan secara optimal karena berbagai kendala yang dihadapi.

Penjelasan terhadap program yang tidak optimal tersebut paling tidak dapat dirujuk secara teoretis pada teori yang dikemukakan oleh VanMeter and van Horn (1975), Cheema dan Rondinelli (1983), serta George Edward III (1990) (lihat Subarsono, 2011). Ketiga teori tersebut menjelaskan bahwa salah satu faktor yang memengaruhi implementasi suatu kebijakan adalah faktor sumber daya. Wawancara kepada para pemangku kepentingan, khususnya Organisasi Pemerintah Daerah (OPD) yang terlibat langsung dalam pelaksanaan kebijakan pelayanan lansia, menjelaskan bahwa persoalan utama yang dihadapi adalah kecukupan sumber daya manusia, terutama kualitasnya, dan sumber daya keuangan (anggaran). Satu hal penting yang juga perlu dicatat adalah infrastruktur yang kurang memadai telah menyebabkan terhambatnya pelaksanaan program di lapangan. Sementara itu, faktor struktur organisasi, disposisi dan lingkungan sangat memadai sehingga tidak menjadi fator penghambat dalam implementasi.

\section{Kesimpulan}

Berikut adalah beberapa kesimpulan yang dapat diambil dari penelitian ini.

1. Regulasi terkait perawatan lansia di tingkat nasional, provinsi, dan kota tergolong mencukupi sebagai landasan dalam pelaksanaan program pelayanan lansia jika ditinjau dari sudut pandang normatif.
2. Beberapa regulasi tingkat provinsi tergolong konsisten dengan tingkat nasional, seperti peraturan pembentukan Komisi Nasional Lanjut Usia di tingkat nasional dan Komisi Daerah Lanjut Usia di DIY, peraturan pelaksanaan program penyediaan sarana pelayanan publik, serta peraturan peningkatan kesejahteraan sosial melalui program ASLUT. Hal tersebut serupa dengan beberapa regulasi tingkat kota yang juga telah konsisten dengan tingkat provinsi, seperti peraturan pembentukan Komisi Kota Lanjut Usia di Kota Yogyakarta, penyediaan fasilitas Rumah Sehat Lansia, dan pelaksanaan program ASLUT di Kota Yogyakarta.

3. Terdapat beberapa program perawatan lansia yang telah diimplementasikan di Kota Yogyakarta sebagai bentuk penerjemahan regulasi di tingkat nasional, provinsi, dan kota. Berikut adalah beberapa di antaranya. Pertama adalah program kesehatan, yang terdiri atas rawat Jalan dan kunjungan gangguan jiwa di Puskesmas Kota Yogyakarta, Yogyakarta Emergency Services 118, pelayanan Rumah Sehat Lansia (Rusela), dan pelayanan upaya promosi kesehatan di tempat-tempat Ibadah. Kedua adalah program sosial dan ekonomi, yang terdiri atas Asistensi Sosial Lanjut Usia Terlantar (ASLUT), home care, reguler panti, dan program Usaha Ekonomi Produktif (UEP) . Namun, penerapan program belum optimal karena belum mampu secara signifikan mengatasi seluruh permasalahan lansia, seperti program belum menyentuh seluruh lansia yang ada di Kota Yogyakarta, masih terdapat fasilitas publik yang belum ramah lansia ditinjau berdasarkan aksesibilitasnya, dan pengetahuan lansia terkait program 
tergolong kurang. Pelaksanaan program yang tidak optimal tersebut, terutama terkait dengan ketersediaan kualitas sumber daya manusia yang belum memadai dan keterbatasan anggaran.

\section{Daftar Pustaka}

Abikusno, N. 2007. Older Population In Indonesia: Trend, Issues, And Policy Responces. Jakarta: UNFPA.

Astuti, M., Sauqi., dan Ariani, D. 2016. "Implementasi Kebijakan Asistensi Sosial Lanjut Usia Telantar". Jurnal Sosio Konsepsia, 5 (1).

Badan Pusat Statistik. 2015. Statistik Penduduk Lanjut Usia 2014. Jakarta: BPS.

-----. 2017. Survei Sosial Ekonomi Nasional Kor 2017. Jakarta: BPS.

-----. 2018a. Proyeksi Penduduk Daerah Istimewa Yogyakarta Tahun 2015-2025. Yogyakarta: BPS.

-----. 2018b. Statistik Penduduk Lanjut Usia 2017. Jakarta: BPS

Bappenas. 2015. Perlindungan Sosial Lanjut Usia. Depok: Bappenas.

BKKBN. 2014. Paket Modul: Bina Keluarga Lansia. Yogyakarta: BKKBN.

BPPN, BPS, UNFPA. 2018. Proyeksi Penduduk Indonesia (Indonesian Population Projection) 2015-2045. Jakarta: Badan Perencanaan Pembangunan Nasional, Badan Pusat Statistik, United Nations Population Fund.

Dunn, W.N. 1994. Public Policy Analysis: An Introduction Second Edition. New Jersey: Practice-Hall, ASchimon \& Schuster Company, Englewood Cliffs.

Kementerian Koordinator Bidang Pembangunan Manusia dan Kebudayaan. 2015. Analisis Kebijakan Pemberdayaan dan Perlindungan Sosial Lanjut Usia. Jakarta: Deputi Bidang Koordinasi
Penanggulangan Kemiskinan dan Perlindungan Sosial.

Khotimah, N., Gunardo., Ghufron, A., Sugiharti, S., dan Aryekti, K. 2016. "Lanjut Usia(Lansia) Peduli Masa Depan di Daerah Istimewa Yogyakarta". Jurnal Geomedia, 14 (2), 51-66.

Lembaga Demografi UI dan HelpAge International. 2012. Hasil Penelitian Asistensi Sosial Untuk Usia Lanjut. Jakarta: Lembaga Demografi UI.

Pasolong, H. 2007. Teori Administrasi Publik. Makassar: ALFABETA.

Pemerintah Republik Indonesia. 1998. Undang-Undang Nomor 13 Tahun 1998 tentang Kesejahteraan Lanjut Usia. Jakarta: Sekretariat Negara.

Pemerintah Republik Indonesia. 2009. Undang-Undang nomor 11 tahun 2009 tentang kesejahteraan sosial. Jakarta: Sekretariat Negara.

----. 2009. Undang-Undang Nomor 36 tahun 2009 tentang kesehatan. Jakarta: Sekretariat Negara.

-----. 2016. "Lampiran Peraturan Menteri Kesehatan Nomor 25 tahun 2016 tentang Rencana Aksi Nasional Kesehatan Lanjut Usia tahun 2016-2019". Jakarta: Kementerian Kesehatan.

Rachmiyati. 2011. Pedoman Kelompok Usaha Bersama. Jakarta: Kementerian Sosial Republik Indonesia, Direktorat Jenderal Pemberdayaan Sosial dan Penanggulangan Kemiskinan.

Ramdhani, A., dan Ramdhani, M. A. 2017. "Konsep Umum Pelaksanaan Kebijakan Publik". Jurnal Publik, 11 (1), 1-12.

Rangkoly, I., Rumapea, P., dan Dengo, S. 2014. "Implementasi Kebijakan Bantuan Kesejahteraan Lanjut Usia Di Kecamatan Tanimbar Selatan Kabupaten Maluku Tenggara Barat". Jurnal Administrasi Publik, 2 (3), 39-50. 
Rustatiningsih. 2015. "Peranan Home Care dalam Mendukung Aktifitas Lanjut Usia di Kecamatan Mlati Kabupaten Sleman". Tesis. Penyuluhan dan Komunikasi Pembangunan UGM.

Saputro, S., Rustama, A., Sudarsana., Kusnandar., Istiqomah, N., Khoiriyah, S., Tantri, D., Karyanta, N.A. 2015. Analisis Kebijakan PemberdayaandanPerindungan Sosial Lanjut Usia. Jakarta: Deputi Bidang Koordinasi Penanggulangan Kemiskinan dan Perlindungan Sosial.

Silviany, M. 2015. "Implementasi Kebijakan Kesejahteraan Sosial Lanjut Usia Di Kecamatan Palu Barat Kota Palu". Jurnal Katalogis, 3 (5), 77-85.

Subarsono, AG. 2011. Analisis Kebijakan Publik (konsep. teori dan aplikasi). Yogyakarta: Pustaka Pelajar.

Suriastini, Ni Wayan, Yuda Turana, Firman Witoelar, Bondan Supraptilah, Teguh Yudo Wicaksono, dan Endra Dwi M. 2016. "Angka Prevalensi Demensia: Perlu Perhatian Kita Semua". Policy Brief. Yogyakarta: Survey Meter.

Thoha, M. 2012. Dimensi-Dimensi Prima IImu Administrasi Negara. Jakarta: Raja Grafindo Persada.

Yamane, Taro. 1967. Statistics, An Introductory Analysis, 2nd Ed., New York: Harper and Row.

Yanuardi., Fitriana, K. N., dan Ahdiyana, M. 2017. "Evaluasi Kebijakan Sosial Peningkatan Kesejahteraan Lanjut Usia Terlantar (LUT)". Jurnal PKS, 16 (1), HIm. 1-10. 